Bilous Yuriy. Socio-geographical aspects of formation of the general educational complex of regions of Ukraine. Journal of Education, Health and Sport. 2021;11(03): 42-50. eISSN 2391-8306. DOI http://dx.doi.org/10.12775/JEHS.2021.11.03.005 https://apcz.umk.pl/czasopisma/index.php/JEHS/article/view/JEHS.2021.11.03.005

https://zenodo.org/record/4619291

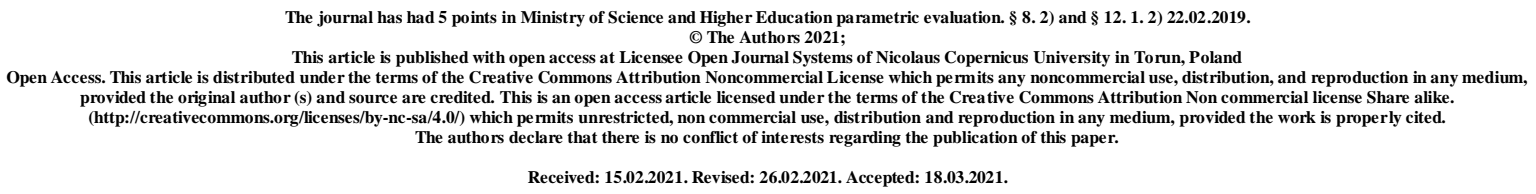

UDC 911.3

\title{
SOCIO-GEOGRAPHICAL ASPECTS OF FORMATION OF THE GENERAL EDUCATIONAL COMPLEX OF REGIONS OF UKRAINE
}

\author{
Yuriy Bilous \\ Yuriy Fedkovych Chernivtsi National University, Ukraine \\ bilous_jura@ukr.net
}

Abstract

The article considers spatial differences in the development of the general educational complex. The main indicators that characterize the level of development of the general educational complex are the coefficient of concentration, the coefficient of localization, social density, the quality of students' knowledge, the number of teachers, and others. Based on these indicators, 5 groups of regions were identified according to the level of development of the general educational complex using Kohonen's self-organizing feature map. As of January 1, 2020, there were 14,815 general secondary education institutions in Ukraine, with 437,981 teachers and more than 4 million students. In general, in Ukraine, there is significant spatial differentiation in the level of development of general secondary education, which contradicts the principles of equality and access to quality educational services.

Keywords: education; general educational complex; general secondary education institution; quality of education. 


\section{Relevance of the research topic}

Education is the main factor in the successful development of the country and its competitiveness. Today, Ukrainian education is undergoing a process of reformation, which involves optimizing the network of general secondary education institutions by creating support institutions and their branches. Education in Ukraine is based on the principles of equality and accessibility for all participants in the educational process. The actual formation of affordable quality education is the first stage in the development of the educational complex of Ukraine.

In Ukraine, there are significant territorial differences in the development of the educational complex. Socio-geographical studies of the educational complex are relevant because they allow identifying territorial differentiation of development of education and invent better ways to optimize further development of education.

\section{Analysis of previous research}

The study of the educational complex by scientists-geographers, at present, is at the stage of active development. The study of education takes place in different aspects: as a separate object of socio-geographical research, as a component of intellectual potential, as a component of human development, as well as the study of its components. The studies of such geographers as O. Kornus, L. Nyemets, Y. Oliynyk, T. Melnychenko, O. Zayachuk, M. Zayachuk, I. Kostashchuk, T. Nych, Y. Bilous, and others are devoted to the study of the general educational complex as a separate direction of socio-geographical research.

\section{The research aims and objectives}

This research aims to analyze the level of development of the general educational complex of Ukraine and its components. Following the aim, we set the following objectives: to determine the methodology of research of the general educational complex; to identify territorial differences in the development of components of the general educational complex of Ukraine; to analyze the level of knowledge of graduates of general secondary education institutions; to carry out typification of regions of Ukraine according to the level of development of the general educational complex.

\section{The main material}

At the state level in Ukraine, a certain territorial organization of the educational complex formed, which can be characterized as a process of purposeful placement of educational institutions, research institutions, service enterprises, education authorities in conjunction with the settlement system and production, resulting in a certain socio-economic 
effect based on meeting the educational needs of the population and the demand of the economy in qualified personnel [5].

Among the elements of the component structure of the educational complex stands out general educational complex. The system of general secondary education in Ukraine consists of the contents of complete general secondary education at each level, the network of educational institutions, participants in the educational process, personnel, financial, scientific, and methodological, resource and regulatory support of educational and administrative activities in general secondary education. General secondary education is obtained at 3 levels: primary education; basic secondary education; vocational education [11].

In total, in Ukraine, as of January 1, 2020, there are 14,815 general secondary education institutions. More than 1,000 institutions are located in Lviv and Donetsk oblasts, and less than 400 in Kirovohrad, Kherson, and Chernivtsi oblasts. In urban areas, the largest number of GSEI (general secondary education institutions) are located in the Dnipropetrovsk region and the city of Kyiv - 559 institutions each. The fewest educational institutions in urban settlements (less than 200) are in Chernivtsi, Volyn, Luhansk, and Ternopil oblasts. If we consider rural areas, the largest number of institutions are located in Ivano-Frankivsk, Ternopil, Vinnytsia, and Lviv oblasts (more than 500 institutions), the least (less than 200) institutions - in Donetsk, Kirovohrad, and Luhansk oblasts. 437981 teachers are working in GSEI, in particular 187789 teachers in rural areas and 250192 teachers in urban areas. Most teachers, more than 25,000, work in Kyiv, Dnipropetrovsk, and Lviv oblasts. The lowest number is (less than 11,000) in Luhansk, Sumy, and Kirovohrad oblasts. As for students, as of January 1, 2020, there were 4,191,538 students. Among them, 298,296 students studied in the urban areas and 120,9342 in rural. The largest number of students located in Kharkiv, Odesa, Lviv, Dnipropetrovsk oblasts, and Kyiv (more than 250 thousand), less than 100 thousand students study in Luhansk, Kirovohrad, Chernihiv, and Sumy oblasts [1].

To identify the compliance of the territorial location of general secondary education institutions to the needs of the population, we calculate the concentration ratio of GSEI according to the formula [6]:

$$
K_{t k}=\frac{p \times S}{P \times S}
$$

where $K_{t k}$ is the coefficient of territorial concentration of GSEI; $p$ - the number of institutions in the region; $S$ - total area of Ukraine; $P$ - number of institutions in Ukraine; $s-$ total area of the oblast. 
At $K t k<1$ we can talk about a low concentration of institutions; if Ktk approximate to 1 - about the optimal ratio of the studied indicator; and if $K t k>1$, that there is a high concentration of institutions in the area.

In Ukraine, 10 oblasts have a low concentration of institutions: Kirovohrad, Kherson, Chernihiv, Sumy, Mykolaiv, Zaporizhia, Poltava, Zhytomyr, Kharkiv, and Odesa oblasts. The optimal ratio observed in only 4 oblasts (Kyiv, Cherkasy, Luhansk, Dnipropetrovsk) and a high concentration of institutions in 10 oblasts and the city of Kyiv (Fig. 1).

The indicator is the coefficient of localization of general secondary education is no less important. It is calculated by the formula [6]:

$$
\text { Кл }=\frac{p \times N}{P \times n}
$$

where $K \pi$ is GSEI localization coefficient; $p$ - the number of institutions in the oblast; $P$ - number of institutions in Ukraine; $n$ - population of the oblast; $N$ - the population of Ukraine.

If $K л .<1$, we can talk about the low level of localization of GSEI; Kл. approximate to 1 - the average level of localization; $\kappa_{л}$. $>1$ - high level of localization.

We can see a high level of localization in 17 oblasts of Ukraine: Sumy, Kherson, Kyiv, Poltava, Mykolaiv, Chernivtsi, Cherkasy, Lviv, Chernihiv, Ivano-Frankivsk, Vinnytsia, Khmelnytsky, Zakarpattia, Rivne, Zhytomyr, Volyn, and Ternopil. Whereas the city of Kyiv has only - 0.5. The rest of the oblasts have an average level of localization (Fig. 1).

An important indicator that characterizes the level of development of the network of GSEI of the oblast is the social density, which makes it possible to analyze the network of GSEI and establish the compliance of institutions to the existing settlement network in the oblast. The calculation of the coefficient of social density SGEI was carried out according to the following formula [3]:

$$
\mathrm{C} 30=\frac{30}{\mathrm{Hn}}
$$

where $\mathrm{C} 30$ is the social density of the GSEI network; 3o - the number of GSEI; Нп the number of settlements. 


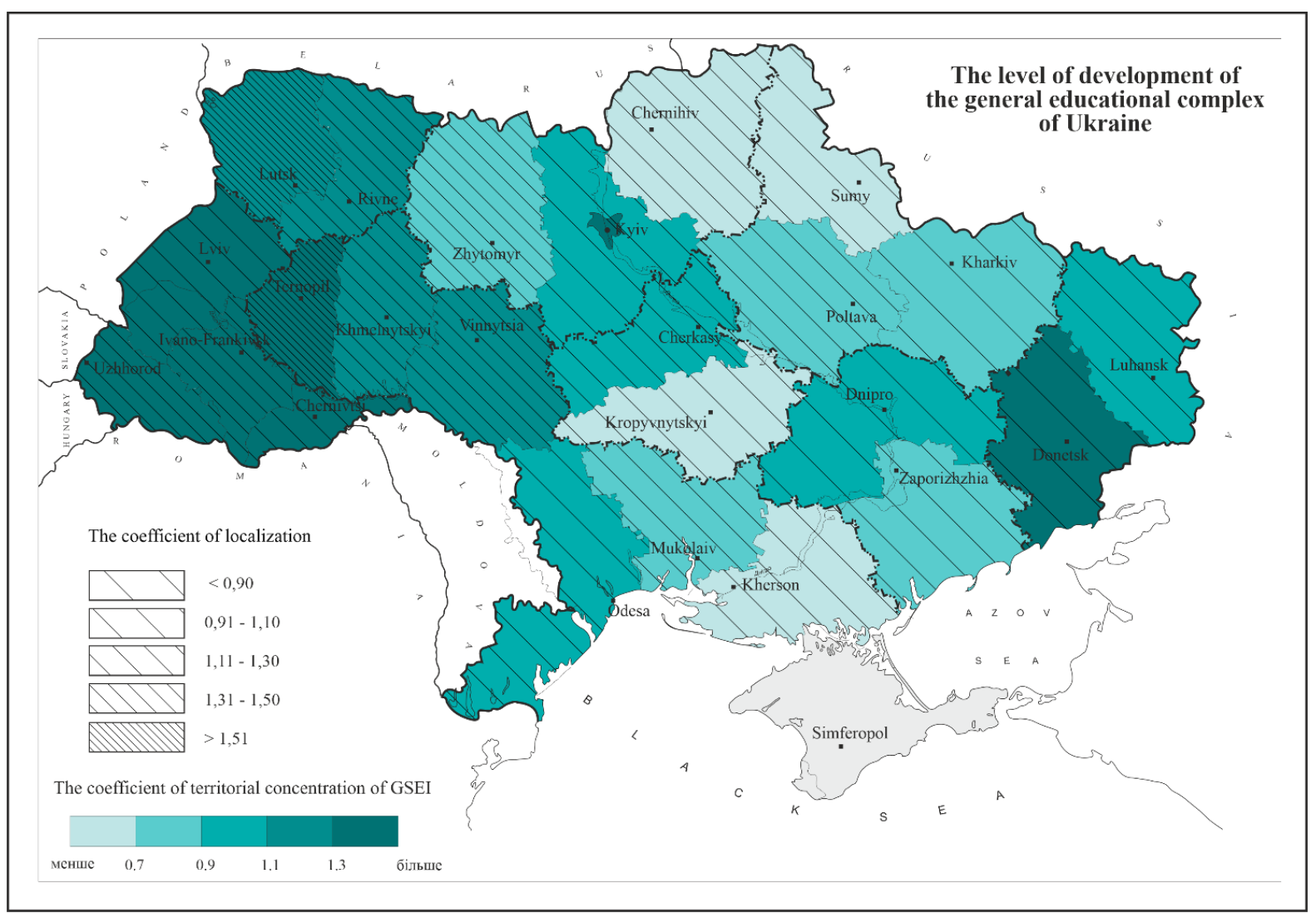

Fig. 1. The level of development of the general educational complex of Ukraine

The highest coefficient of the social density of GSEI is in the city of Kyiv and Zakarpattia oblast - more than 1; and the worst indicator is observed in Sumy, Kirovohrad, Chernihiv, and Poltava oblasts - 0.3. The rest of the oblasts are characterized by the average coefficient of the social density of GSEI (Fig. 2).

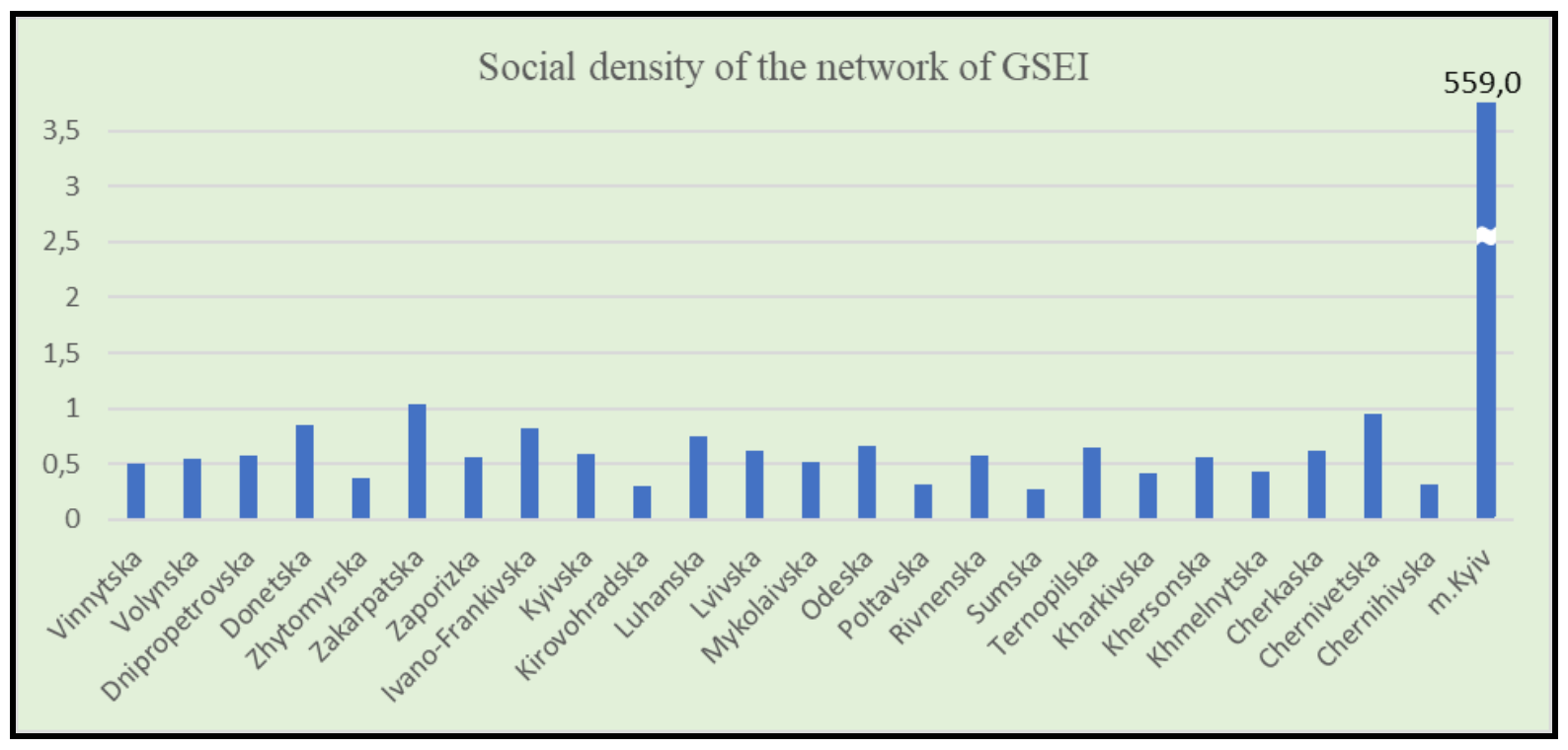

Fig. 2 Social density of the network of GSEI 
The best provision of the population with GSEI can be observed in Zakarpattia, Rivne, Zhytomyr, Volyn, and Ternopil oblasts - more than 5 institutions per 10,000 people. As for the lowest amount of provision, we can observe it in Dnipropetrovsk, Donetsk, Kharkiv oblasts, and the city of Kyiv - 2.7 and 1.9, respectively.

When characterizing the general educational environment, the study of the level and quality of students' knowledge deserves special note, as it is being the result of the interconnection of all its components.

The quality of knowledge is one of the main criteria for assessing learners' knowledge quality. It includes completeness, depth, awareness, systematicity, flexibility, specificity, generalization, which are identified in the analysis of the results of learning and use of knowledge. During the study and assessment of the quality of knowledge, three levels are outlined: reproductive, constructive, and creative. Knowledge acquires new qualities as learners learn new elements or types of learning content.

The most representative indicator of determining the level and quality of graduates' knowledge is external independent evaluation. An external independent testing (ET) is a set of organizational procedures (primarily testing) aimed at determining the level of academic performance of graduates of secondary schools when they enter higher education institutions.

Analyzing the data of the results of the External Testing in 2019, we can say that the largest number of participants was in the Ukrainian language and literature - 339385, of which 315744 passed this subject as the SFE (state final examination). Overall in Ukraine, the average score in the Ukrainian language and literature was 141.1. The worst score was observed in Zakarpattia (132.4) and Chernivtsi oblasts (133.2). Students from Kharkiv (144.1), Kyiv (144.2), Lviv oblasts (146.8), and the city of Kyiv (148.0) had the best knowledge of the subject.

The history of Ukraine was passed by 222537 participants, and only 196727 of them were elected as SFE. The average score on the subject in Ukraine is 135.5. The lowest results were again shown in Zakarpattia (127.7) and Chernivtsi (131.1), and Mykolaiv oblast (131.9). But the highest score was in Cherkasy (137.7), Kharkiv (138.5), Lviv oblasts (140.0), and the city of Kyiv (140.7).

In 2019, the ET in Mathematics consisted of 155319 participants, among whom 122253 chose it as the SFE. The average score was 139.4 points. This time the lowest scores were received by Kirovohrad (134.4), Luhansk (135.0), Mykolaiv (135.2), and Vinnytsia oblasts (135.4). The highest scores were received by Volyn (141.4) and Lviv oblasts (143.2), and the city of Kyiv (147.3). 
The number of participants in the ET in Physics in 2019 was only 21407, of which only 10325 participants chose the subject as the SFE. In general, the average score in Ukraine was 136.3. The lowest score was received by Odesa (129.0), Zakarpattia (130.2), and Luhansk oblasts (130.2). The highest in Volyn oblast (140.1) and the city of Kyiv (147.5).

As for the ET in chemistry, only 13700 students chose the subject in 2019; and only 3558 of them took it as the SFE. The score is higher than the average results of the ET of previous subjects - 144.7 points. The best knowledge in chemistry was shown by Ternopil (152.0) and Lviv oblasts (154.7), and the worst in Kherson (134.9), Luhansk (135.2), and Kirovohrad oblasts (137.7).

ET in biology in 2019 was chosen by 76020 participants, of which 51025 took it as the SFE. The average score on the subject - 139.2. Zakarpattia, Kherson, Rivne, and Chernivtsi oblasts scored less than 135 points, while Lviv oblast and the city of Kyiv scored more than 145 points.

ET in geography was taken by 75039 participants, of which 45221 chose it as the SFE. The average score was 139.8 points. Kyiv (144.4) and Sumy oblasts (144.5) stand out with the best knowledge of geography, and Zakarpattia (128.1) and Chernivtsi oblast (134.0) showed the worst result.

The ET in English language was taken by 91177 participants, of which 55878 took it as SFE. The average score on the subject is the highest among others and equals 146.5. The lowest score in English was in Luhansk (139.1), Donetsk (140.4), Mykolaiv (141.5), and Kherson (141.6) oblasts. The highest score was shown by Chernivtsi (150.1) and Lviv oblasts (150.3), and the city of Kyiv (155.6).

Based on this data, the administrative regions of Ukraine were grouped according to the level of development of the general educational complex by creating Kohonen's selforganizing feature map (Fig. 3).

One of the most difficult and complicated issues of grouping was choosing the optimal number of clusters. It was determined that it is most expedient to allocate 5 clusters of regions of Ukraine according to the level of development of the general educational complex:

Cluster 0: Kyiv, Poltava, Sumy, Cherkasy oblasts;

Cluster 1: Dnipropetrovsk, Donetsk, Zaporizhia, Kirovohrad, Luhansk, Odessa, Kharkiv oblasts;

Cluster 2: the city of Kyiv;

Cluster 3: Vinnytsia, Zakarpattia, Mykolayiv, Kherson, Chernivtsi oblasts; 
Cluster 4: Volyn, Zhytomyr, Ivano-Frankivsk, Lviv, Rivne, Ternopil, Khmelnytsky, Chernihiv oblasts;

In general, in Ukraine, there is significant differentiation in the development of the general educational complex.

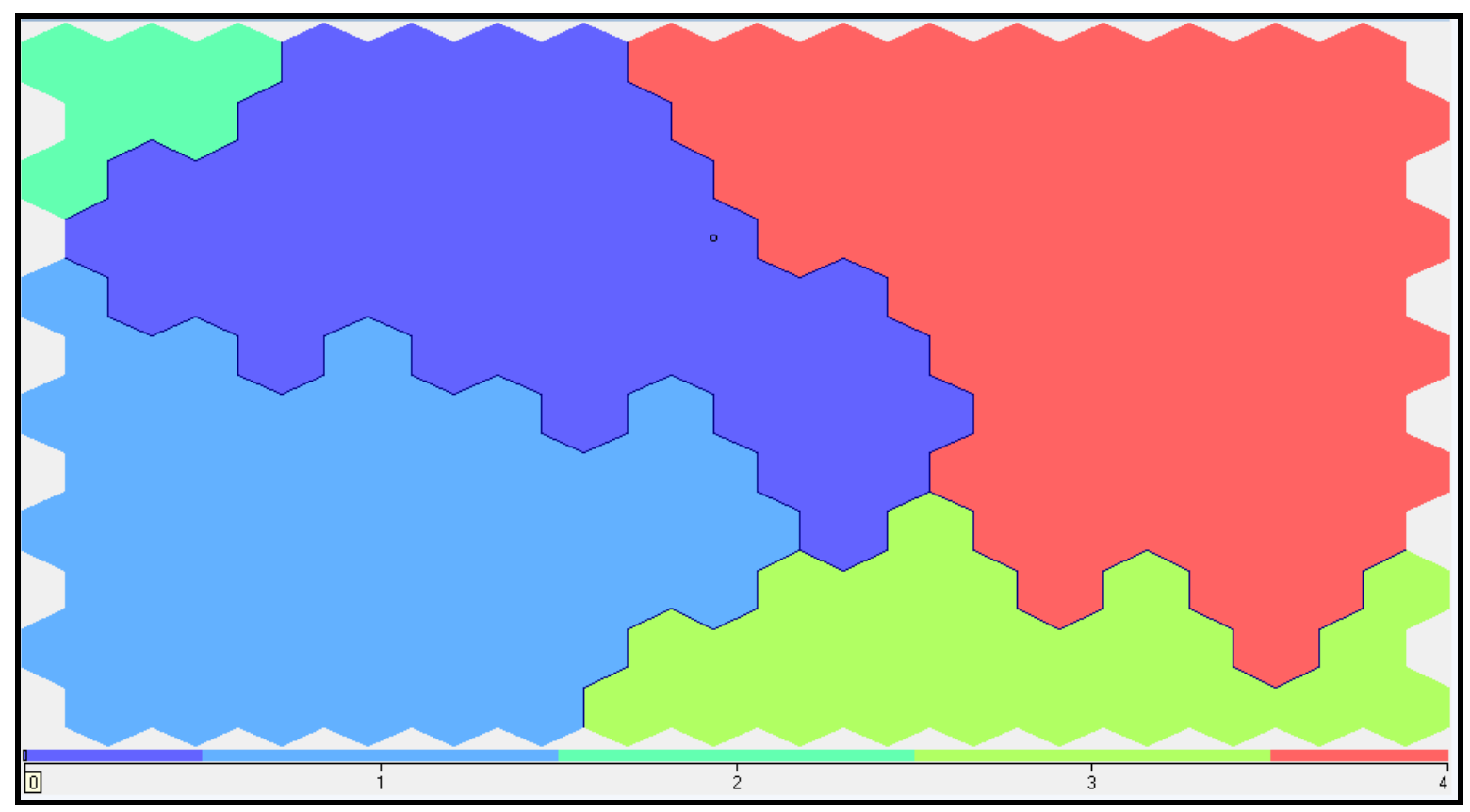

Fig. 3. Kohonen's self-organizing feature map

Conclusion. In Ukraine, a set territorial organization for the general educational complex has been formed, which can be characterized by placing GSEI, service enterprises, and education management bodies in connection with the settlement and production systems. General secondary education in Ukraine is obtained at 3 levels: primary education; basic secondary education; vocational education. To characterize the level of development of general secondary education, several indication methods are used. The most important among them are GSEI, the number of teachers, the coefficient of concentration, the coefficient of localization, social density, quality of students' knowledge, and others.

In Ukraine, there is significant territorial differentiation in the development of the general educational complex of the regions. Notably, unevenness can be observed between rural and urban settlements. The reasons for this unevenness lies in several factors, including physical-geographical and socio-economic conditions of the territory, historical background, and others.

Series of measures need to be taken to ensure equal access to quality general secondary education in Ukraine. 


\section{References}

1. Institutions of general secondary education in 2018-2019 and 2019-2020 academic years: newsletter. Institute of Educational Analytics. Retrieved from https://iea.gov.ua/byuleteni/.

2. Zaiachuck, O. (2013). Methodology and methods of socio-geographical research of the territorial organization of the educational complex of the regions. Scientific bulletin of the Lesia Ukrainka East European National university. Geographical sciences, (16), 132-137.

3. Kornus, O. (2012). Socio-geographical aspect of preschool education development in Sumy oblast. Human geography journal, 12(1), 111-118.

4. Kornus, O. H., Nyemets, K.A., Nyemets, L. M., \& Kornus, A. O. (2009). Sphere of service of population of Sumy oblast: social and geographical aspects. KharkivSumy.

5. Melnychenko, T. Y. (2005). Educational complex in Ukraine: current state and dicertions of improvement of territorial organization. Extended abstract of candidate's thesis. Kyiv.

6. Oliynyk, Y. B., Nych, T. V., Nych, O. M., \& Tanasiychuk, D.V. (2017). General secondary education in Ukraine: current state and development prospects. Geography and tourism, (40), 131-137.

7. Pavlovska, T.S., Prytula, I.I., \&. Fedchyk, A.P (2019). Current state of educational complex of Volyn oblast. Scientific thought of present and future : 26-th AllUkrainian practical-cognitive conference. (pp. 38-42). Dnipro : NM

8. Results of external independent testing - 2016, 2017, 2018, 2019, 2020 : regional data. UCEQA (Ukrainian Center for Educational Quality Assessment). Retrieved from https://zno.testportal.com.ua/stat .

9. Symonenko, A.M. (2008). Socio-geographical analysis of the educational complex of the regions (theoretical and methodological approach). Scientific notes of $M$. Kotsyubynsky Vinnytsia State Pedagogical University. Series: Geography. 1, 115-129.

10. Topchiyev, O.H. (2005). Socio-geographical research: methodology, methods, techniques Odesa: Astroprynt

11. Law of Ukraine “On Education” : adopted 5 September 2017 № 2145-VIII. Retrieved from https://zakon.rada.gov.ua/laws/show/2145-19\#Text 